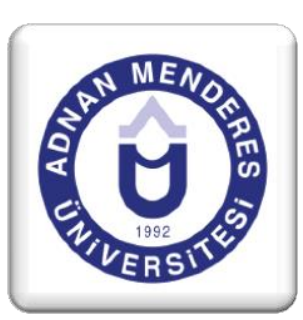

\title{
Ulus Bilincine Dayanan Yahveizmin Evrensel Boyuttaki Tektanrıcılık İnancı İle Çelişkisi
}

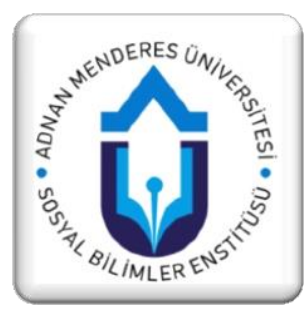

\author{
Kürşat Haldun AKALIN*
}

\begin{abstract}
Özet
Yahve'nin planı, çocuklarını kendi varlığı hakkında bilgili kılarak, onları batıl inançlardan ve yalandan koruyup kurtararak aydınlatmanın, yanı sıra işiyle ilgili kesin bir tasarımını açıklamaktır. Yahve'nin tasarımı, özel bir halkın aracılığını, özel bir kitabı ve özel bir hukuku gerektirmektedir. Aracılık işlevinden dolayı İsrail ulusu Tanrı tarafından niçin seçilmiştir? Bu, Yahve'nin dinine ayıkırı bir durumdur. Yoksa Yahve, bütün ulusların yaratıcısı değil midir, bütün halklara karşı eşit derecede sevgili değil midir? Yoksa insanlar karşısında aciz midir veya insanlar başı boş mudur? Duyulan inanç, Yahve'nin gerçek bir Tanrı olduğu, yarattığı insanlar arasında hiçbir ayrım yapmadığı ve bir tek halka ulusal ya da ırksal bir üstünlüğü vermediğidir. Yahve Kendisini tek olarak göstermekte, diğer ulusları reddetmekte, kendinden daha büyük derecedeki bir ilahı tanımamaktadır.
\end{abstract}

Anahtar Kelimeler: Tektanrıcılık, Yahveizm, Ulusal din

The Contradiction of Yahwehism that Depended on National Consciousness with Monotheistic Faith that World-Wide Dimension

\begin{abstract}
In Yahweh's plan to illumine His children with the knowledge of His being and to redeem them from superstition and falsehood a certain design is clearly at work. It involves the mediation of a particular people, a particular book and a particular law. Why Israel nation was chosen for their mediating role? This is the contradiction of Yahweh's religion. Is Yahweh not the creator of all nations and should not all peoples be equally precious to Him? The belief that if Yahweh was a real God, he didn't make a discrimination among his creatures and didn't give to the one nation national or racial superiority. Yahweh taken to Himself one and to the exclusion of the other or to a greater degree than another.
\end{abstract}

Keyords: Monotheism, Yahwehism, National religion

*Doç. Dr., Osmaniye Korkut Ata Üniversitesi, akalinhaldun@yahoo.com 


\section{Giriș}

İsraillilerin Tanrı kavramı, dürüstlüğü ve yasasıyla ilgili dinsel inançları dikkâte alındığında; M.Ö. 350 ile M.S. 50 yılları arasındaki dört asırlık bir dönem boyunca hiç bir değişiklik göstermemiş olduğunu, cennet ve cehennem gibi kavramların Musa tarafından yazılan ve nesillere aktarılan Tevrat'ta bulunmadiğını, öbür dünyayla ilgili bu tür yorumların M.S. 70 ile 630 yılları arasında geliştirilmiş olan Rabbinik yazınında oluşturulduğunu açıkça söylemek pek çok kimseye şaşırtıcı gelecektir. Öldükten sonra başlayacak yaşamla veya dirilişle ilgili anlam içeriklerinin belirlenmesi, İsraillilerin dinsel inançlarının tahmininde çok önemli bir yer tutmaktadır. Zira ölümden sonraki dirilişle ilgili fikirlerde meydana gelebilecek bir değişiklik, İsraillilerin dininin tamamında bir farklılaşmaya yol açacaktır. Bu dört asırlı dönem boyunca İsraillilerin Tanrı buyruğu üzerine kurulu olan ve mükemmelliğine inanmış oldukları Kitaba bağlı kalarak dinsel inançlarını şekillendirmiş olmaları, Eski Ahit'in uzun yıllar süren çeşitli birikimlerinin bir ürünü olarak ortaya çıkmış bulunması; dindeki esas ilginin, geçmişten devralınan bu kutsal metinlerin üzerinde toplanmasına yol açmıştır. Oysa, nispeten çok kısa bir süre içerisinde oluşturulmuş olan Yeni Ahit, bu bakımdan, çok daha güçlü bir şekilde anlam birliği temeli üzerine kurulmuştur.

İsraillilerin diniyle ilgili araştırma yapan her hangi bir kimse dahi, İsa'nın, sözlerinde ${ }^{1}$ ne kadar haklı olduğunu derhal fark edecektir. İsa'nın zamanına kadar gelen Eski Ahit'in kutsal metinleri, yüce ve sonsuz gerçekleri yalnızca bildirmekle kalmamakta; fakat bununla birlikte, davranışlar ve düşünceler üzerinde mutlak bir hakimiyet kurarak, gelenekselleşerek bir yaptırım gücüne de kavuşmaktadır. Eski Ahit'in tüm ifadelerinin en kutsal birer hazine olarak nesillere aktarılmış olmasına rağmen; Tanrının bütün insanların tek yaratıcısı ve tek Tanrı'sı olduğu, herkese karşı bağışlayıcı ve lütufkâr bir yaklaşım sergilediği vs., içeriğindeki fikirlerin oluşturulamamış olmasi; Yeni Ahit'in, Eski Ahit üzerindeki üstünlügüünün neredeyse temelini meydana getirmiş̧tir. Oysa, daha başlangıçtan beri Tanrı, tüm insan nesli ile bütün evreni yaratan ve var olan her yaratığı üzerinde de kesin bir hakimiyet kuran tek Tanrı olma yerine; sanki Firavun'u Kendisi yaratmamış gibi, İsraillilerin düşmanlarını düşman edinerek onlara karşı amansızca savaşan; Firavun'un kendisine doğrudan içten hakim olma yerine, kudretiyle onu diştan durdurma veya ikna etme yoluna giden savaşçı bir ilâh kisvesine bürünmüştür.

\section{Tek Tanrı Kavramı}

İsrailliler, diğer uluslardan çok uzunca bir süre önce, tek Tanrı düşüncesine ulaşmışlardır. Yaratmış olduğu bu dünyadan tamamıyla ayrılmış olan Tanrı, özellikle de İşaya'da sözü edilen haliyle, bedensel olmak yerine bütünüyle ruhsal bir özellik taşımaktaydı. Ancak Yahve'nin havanın içine girerek rüzgârla bir yerden başka yere

\footnotetext{
1 "Kitapları araştırıyorsunuz, çünkü siz ebedi hayatınızın onlarda olduğunu sanıyorsunuz." (Kutsal Kitap, 2004; 1236)
} 
gitmediği, ateşin veya toprağın içinde bulunmadığı açıkça belirtilerek ${ }^{2}$ ruh olmadığı vurgulanmıştır. Nitekim, Eski Ahit'teki, bazı ifadeleri ${ }^{3}$ okuyan bir kimse, Tanrının, tıpkı bir insan biçiminde olduğu anlamını içeren fikirden, muhtemelen, uzaklaşmış olacaktır. Tanrının her yerde bulunma ve her sözü işitme gücü, Eski Ahit'teki, şeklindeki Davud'un niyazından ${ }^{4}$ ve Süleyman'ın mesellerinden ${ }^{5}$ bilinmektedir.

Böylece, Tanrının her şeyden üstün olarak yapayalnız bir halde bulunması düşüncesinden, bu dünyanın dışında olduğu kadar içinde de bulunduğu inancına ulaşmak, hiç de zor olmayacaktır. Özellikle de, Tanrının insanla daha ezelden kurmuş olduğu bağıntısı dikkâte alındığında; Tanrı, Kendisine tapınan ve sevgiyle bağlılık duyan her sâlih kimsenin daima yakınında olduğu sonucuna ulaşılabilir. Tanrının Kendisini tanıtmak istemesi ve ilham yoluyla bildirme gayesini taşıması, yanar gibi görünen bir çalıdan seslenmesi; İsrailli din bilginlerince üzerinde hiç düşünülmemiş bir konu değildir. Dağda yanıp da hiç tükenmeyen bu çalının arkasından Tanrının Musa'ya seslenmesi; Tanrının yarattığı insanla konuştuğu, her zaman insana yakın olduğu, Kendisine söylenen her şeyi işittiği, insanın kalbindeki en gizli niyetlerinden daima haberdar olduğu, eyleminin her haline vukuf olduğu vs., gibi düşüncelerin İsrailliler arasında daha da rağbet bulmasına yol açmıştır. Böylece, her yerde var olan ve her şeye karşı da mutlak bir üstünlük kuran Tanrı; yarattığı insandan tümüyle haberdar olduğu gibi, onu başıboş bir halde kendi haline bırakmış da değildir. İsrail'in fazilet öğretisi, Tanrıdan geldiğine inanılan tapınak ile yasa anlayışı üzerine kurularak, günaha ve yabancı ilahlara tapınmaya karşı kesin tavrını almasıyla şekillenmiştir.

Tanrının seçtiği kişiyle kurmuş olduğu bu yakınlığı, Tanrının insanla olan ilişkisinin açıklanmasında, sonradan çok ilginç teorilerin ortaya çıkmasına yol açmıştır. Bu teorilere göre, insan, Tanrının yaratmış olduğu çok özel ve müstesna bir yaratığı olmakla, Tanrının suretini taşımaktadır. Adem'in nesli olan bütün bu insanlar, yeniden her yaratılışlarında ilâhi suretlerini de yinelemiş olmalarıyla; tüm insan ırkının birliğini ve büyüklüğünü kanıtlamış olmaktadırlar. Tanrı ve insanlarla ilgili sorular $^{6}$, İsrailli ile dünyanın diğer ulusları arasındaki farklılığın üzerinde

\footnotetext{
2 “Rab Yahve, dağa çık ve önümde dur, yanından geçeceğim, dedi. Rab’bin önünde çok güçlü bir rüzgar dağları yarıp kayaları parçaladı. Ancak Rab Yahve, rüzgarın içinde değildi. Rüzgarın ardından bir deprem oldu, Rab Yahve, depremin içinde de değildi. Depremden sonra bir ateş çıktı, ancak Rab Yahve ateşin içinde de değildi. Ateşten sonra yumuşak bir ses duyuldu. İlyas sesi duyunca, cüppesiyle yüzünü örttü. O sırada bir ses, burada ne yapıyorsun İlyas, dedi.” (Kutsal Kitap, 2004; 684)

3 "Rab, size ateşin içinde söyledi, siz sözlerin sesini işittiniz, fakat bir suret görmediniz, yalnızca bir ses işittiniz. Yapasınız diye size emrettiği ahdini, on emrini size bildirdi, onları iki taş üzerine yazdı. Canlarınızı iyi koruyun, çünkü Horebde, ateşin içinden Rab size söylediği gün, bir suret görmediniz.” (Kutsal Kitap, 2004; 759)

4 "Ya Rab, beni denedin ve beni bildin. Oturuşumu ve kalkışımı Sen bilirsin, düşüncemi uzaktan anlarsın. Bütün yollarımı iyi bilirsin. Dilimde bir söz yokken, Sen onu tamamen bilirsin. Gizli yerde yaratıldı̆̆ım zaman, bedenim Sana gizli değildi." (Kutsal Kitap, 2004; 693)

5 “İnsanın yolları, Rab'bin gözü önündedir. Sevgi, her suçu örter. İyi adam Rab'den lütuf bulur. Adamın yüreği, kendi yolunu tasarlar; fakat onun adımını Rab kılavuzlar. Fakire acıyan, Rab'be ödünç verir. Yürekleri tartan Rab'dir. Yürekleri tartan anlamaz mı? Senin canını koruyan hiç bilmez mi? İşine göre insana ödemez mi?" (Kutsal Kitap, 2004; 802)

6 "Tanrının insanlara sunduğu iyiliği ve merhameti, insanı Kendi suretinde yaratmıs olmakla Adem'in neslini sevgili görmüş, yarattığı bütün varlıklar üzerinde insanı hakim ve değerli kılmıs, hizmette de bütün meleklerden önce gelmiştir. Bütün insanların atasını, yalnızca Adem'in soyu olarak bir tek kişide toplamış olmakla, kişiler
} 
odaklaşmakta olduğundan; İsraillinin Tanrının seçtiği tek ulus olduğuna inanıldığ halde, hâlâ esaret ve gerilik içinde bulunması bir türlü açıklanamamakta; tanrının kendisine dua eden her insanı duyduğunu belirten Talmud'daki mesaj1 ${ }^{7}$, İsrailli olmayan için kesinlikle yorumlanmamaktadır. Kaldı ki Kutsal Kitap’taki bir ifadeden $^{8}$ de açıkça anlaşılacağı gibi, Tanrı yarattığı her insan için iyidir ve de merhametlidir; İsrailli olmayanların neredeyse tamamı yabancı ilahlara taptıkları ve günahkâr oldukları için, fiili veya potansiyel olarak İsrail'in düşmanı haline geldiklerinden dolayı, bütün bu insanlar Tanrının düşmanıdırlar ${ }^{9}$. İradesini nebileri aracılığıyla bildiren Tanrı, her şeye gücü yettiği halde, sözünü insanlara kabul ettirememektedir.

Oysa, bütün insanları yaratmış olan Tanrının bu uluslara açıkça düşmanlığını ilan etmesine ne gerek vardır ki; yine, mesajını seçtiği nebisi vasıtasıyla insanlara bildirmesinin sebebi ne olabilir ki; Tanrı zaten kişinin bedenine, hayatına ve bütün kaderine hakimdir, kalbindeki en gizli niyetlerine aşikârdır; o halde, sonsuz kudretiyle, insanın zihnine ve tavrına neden hakim olamasın? Kitapla, yasayla, örnek olarak seçtiği nebisiyle insanları Kendisine çağırmakla, Tanrı, dıştan insan üzerinde baskı kurmak yerine; niyazları işitmesiyle, onlarla doğrudan dostluk kurmasıyla, neden kişileri içten Kendi yoluna çağırmamakta, herkesin Kendisine özgürce yönelişini kutsamamaktadır? Zira, Tanrı, dürüst olanlara da günah içinde yaşayanlara da Kendi güneşini doğurmakta, herkesin üzerine yağmurunu yağdırmakta ve yarattı̆̆ yaratılış itibarıyla da bütün insanlar tek bir ataya bağlanmış, biri diğerinden asla

arasındaki 'benim babam senin babandan daha üstündür' duygusunu yıkarak, insanlığın barışa yönelme umutlarını pekiştirmiştir. Eğer bütün insanların tek bir atası varsa, herkes sonunda aynı aile ocağından türemişse; insan ile Tanrı arasında kurulmuş olan bu gönül ilişkisi herkesi kapsıyorsa; Tanrının İsrail oğullarıyla kurmuş olduğu bu özel bağıntının sebebi ne olabilir? Diğer uluslar içinde Tanrının sevdiği ve seçtiği hiç mi bir kişi yoktur ki, tüm nebiler yalnızca İsrail içinden çıkmıştır? Tanrı, yarattı̆̆ı insandan ve insanın her halinden daima haberdar olduğuna, onun tüm gizli niyetlerini gözleyip eylemlerinin gizemli emellerine de tamamıyla vukuf bulunduğuna göre; İsrail ulusu dışında, dünyanın her hangi bir köşesinde Kendisine yönelişini beğendiği hiç bir kişi yok mudur ki, tüm nebilerini yalnızca İsrail içinden seçmiştir? Bununla da kalmamış, her olayda açıkça İsrail'in tarafinda yer almış, sanki Mısırlıyı yaratan yine Kendisi değilmiş gibi, İsrail'e karșı olanları Kendi düșmanı olarak ilân etmekten hiç çekinmemiş̧ir? Diğer ulusları Kendisine çağıracak olan kimdir? Yoksa Adem'in neslinden gelen bu ulusların hepsi, milyonlarca yıl boyunca, değersiz birer yaratıklar olarak, kendi hallerine mi terk edilmiştir?" (Joseph 1964; 87 )

7 "Tanrı, yarattı̆̆ı her insanın yakınındadır, bu insanlardan her hangi biri Kendisine bir niyazda bulunduğunda, Kulağını onların ağzına götürür" (Bokser 1951; 49)

8 "Rab, herkese iyidir. Merhametleri de bütün işleri üzerinedir. Rab, bütün düşenlere destek olur. Rab, Kendisini çağıranların hepsine yakındır. Rab, Kendisini sevenlerin hepsini korur. Bütün beşer, mukaddes ismini daima ve ebediyen takdis etsin" (Kutsal Kitap, 2004; 1106 )

9 "Dinle ey İsrail, düşmanlarınıza karşı bu gün cenge giriyorsunuz; yüreğiniz gevşemesin, korkmayın ve titremeyin, onlardan yılmayın. Çünkü, sizi kurtarmak üzere, sizin için düşmanlarınızla cenk etmek için, sizinle beraber giden Tanrınız Rab'dir. Bir şehre karşı cenk etmek için ona yaklaştığın zaman, onu barışıklığa çağıracaksın. Eğer sana sulh cevabı verirse, kapılarını sana açarsa; o vakit vaki olacak ki, içinde bulunan bütün bu kavim sana angaryacı olacaktır, sana kulluk edecektir. Eğer seninle barışıp uzlaşmayıp cenk etmek isterse, o zaman onu kuşatacaksın. Tanrın Rab, onu senin eline verdiği zaman; onun her erkeğini kılıçtan geçireceksin. Ancak, kadınları ve çocukları, hayvanları ve şehirde olan her şeyi, bütün malını kendin için çapul edeceksin. Tanrın Rab'bin sana verdiği düşmanlarının malını yiyeceksin. Tanrı Rab'bin miras olarak sana vermekte olduğu bu kavimlerin şehirlerinden nefes alan kimseyi sağ bırakmayacaksın. Tanrın Rab'bin sana emrettiği gibi bu kavimleri tamamen yok edeceksin. Ta ki, kendi ilâhlarına yaptıkları bütün mekruh şeylerine göre yapmayı size de öğretmesinler; yoksa, Tanrınız Rabb'e karşı suç işlemiş olursunuz.” (Kutsal Kitap, 2004; 911 ) 
farklı yaratılmamıştır. Hepsinin, Tanrının birer suretleri olduğuna inanılmıştır. Böyle olduğu halde, bir taraftan, inanılan bu Tanrının bütün insanları yaratan tek Yaratıcı olduğuna inanılması; diğer taraftan da, çok özel bir şekilde bundan İsrail'in Tanrısı olarak bahsedilerek diğer bütün insanlara açıkça bir cephe aldırılması; çok farklı dönemlerde çeşitli kimseler tarafından yazılmış bulunan Eski Ahit üzerindeki en tartışmalı konulardan biri haline getirmiştir.

\section{Bir Ulus Dini Yahveizmin Dayandığı Temel İlke Olarak Ulus Bilinci}

Evreni ve her bir insanı yaratan Tanrının, İsraillinin yanında savaşçı olarak yer alıp, diğer bütün insanlara açıkça cephe almasıyla başlayan bu tartışmalı yorumlar, neredeyse dinin bütün özüne hakim olmuştur. Nitekim, hem, bütün insanların, İsrail'in bu tek Tanrısını kendilerini yaratan tek ilâh olduğuna inanılması ümit edilerek, sadece İbrahim'in Tanrısına tapınmaları ve dünyada Tanrı birliğinin gerçekleşmesi beklenilmiş; hem de, esaret altında dert ile sıkıntılara uğrayarak ulusal onurları kırılan İsraillilerin, Tanrıdan geleceğine inandıkları Mesih sayesinde kurtulacaklarından emin olunmuştur. Bununla da kalınmamış, Tanrının, bütün bu yapılanlardan olayı öç alacağı ümitle beklenilmiş, böylece kendilerini esir eden ve ülkelerini de istilayla zapteden bu çoktanrıcı zalim güçlerin yok olacakları gün niyaz edilmiştir. Bu nedenle, İsraillilerin tek Tanrı kavramı, bütün insanları kapsayan mükemmel bir uyumu asla beraberinde getirmemiş, sadece ulusların tanrısına tapılmasını yasaklanarak ${ }^{10}$ dine dayalı bir ulus bilinci yaratılmıştır.

Gentile dünyasının çoktanrıcı bu durumu, İsraillilerin kendi dinsel düşüncelerini geliştirmek ya da haklılığını göstermek üzere, neredeyse bir karşı dayanak oluşturmuştur. Kendi dinsel inançlarının ahlâki olan yükümlülükleri, arada sırada da olsa, vicdani sorumluluklarını hiç açığa çıkartmıyor değildir. Ancak yinede, Tanrının, İsrail'e beslediği sevgisi uğruna, yabancı ilahlara tapınanlar ve zalimlere karşı duyduğu ilâhi nefret ve düşmanlık nedeniyle; ilahi dürüstlügünün ve merhametinin geleceği gün, özlemle beklenilmektedir. Bu nedenle, İsrailli, Gentile dünyasının geleneksel bir hale getirdiği yaşama tarzından tamamıyla uzak kalarak, kendi küçük günahlarını bir daha tekrar etmemek üzere nefsine hakim olmaya azmederken; aynı zamanda da, günah ve zulümlerinden dolayı Romalıların dikkâtle ve kesinlikle cezalandırılacağından emin olarak; yıkılışlarıyla, mutlak saadeti sunan Tanrı günlerinin geleceğine olan ümidini daima korumuş; yabanc1 ilahlara

\footnotetext{
10 "Tanrının, özellikle de yabancı ilahlara tapan veya dininden dönen kimselere karşı tutumunun ne olacă̆ı, İsrailli din bilginlerini oldukça meşgul etmiş olan bir konudur. Anımsanacak olunursa, İsrailli için yabancı ilahlara tapınma yalnızca bir hata değil, fakat bundan çok daha fazla, öldürücü bir günahtır. Böyle olunca da, İsrail'in dışında kalan bütün ulusların ilahlara tapınma eğilimlerinin ve adetlerinin olması dolayısıyla Tanrıya açıkça karşı gelen günahkârlar olarak algılanmış olmasına hiç şaşmamak gerekir. Helenizmle ilgilenmemiş İsrailli için, Yunan ve Roma dünyası (Gentile ); zulmün ve adaletsizliğin kol gezdiği, hovardalık ve savurganlığın yaşandığı, günah dolu bir dünyadır. Oysa o yıllarda dindar bir İsrailli, cinsel ilişkilere yönelik çok katı ve aşırı kuralcı bir yaşam sürmektedir. Belki de sırf bu yüzden, cinsel yaşamlarındaki serbestlik anlayışları dolayısıyla ilahlara tapınanlar şehvet düşkünlüğünde çok aşırı gitmişler; gereksiz savurganlıklarıyla zevk alemine dalarak, Tanrının seçtiği bu seçkin ulusa karşı zalimce davranmaktan hiç çekinmemişler; bütün bunların sonucunda da, iyi ahlâklılığın gerektirdiği en basit kurallara dahi uymada, tamamıyla ilgisiz ve de yeteneksiz kalmışlardır. Böylece, kendilerini de yaratan Tanrının cezasıyla eninde sonunda karşılaşarak dünya üzerinden silinip gidecekleri o günde; Mesih'in, tıpkı Musa gibi Tanrının gücünü açığa çıkarttığı o mucizevi kudretini özler ve bekler olmuşlardır." (Epstein 1964; 128-129)
} 
tapınanların da, rast gele olarak ortaya çıkan çok önemsiz erdemliliklerini böylece karşılığının verileceğine inanmıştır.

İsrailli din bilginleri, özellikle de ikinci asırdan itibaren, bütün ulusların dürüstlüğe yöneleceklerine olan inançlarını daima ifade etmiş olduklarından; Roma'nın yıkılışıyla birlikte, bütün Gentile dünyasının zulüm ve haksızlıklarla beslenen zevk ile savurganlık geleneklerinin baş aşağı çevrileceğini; çekilen sstırap ile acıların, böylece, sonunda hoşnutluk ve neşeyi getireceğini ummuşlardır. Tanrının, yabancı ilahlara tapınma geleneklerini terk ederek, yoluna katılanlara karşı tavrı nasıl olacaktır? Bu konu, üzerinde düşünülen bir sorun halini almıştır. Dinsel inançlarının doğal bir sonucu olarak, tüm Gentile dünyasını ilahlara tapınmaları yüzünden cehennem azabına çarptırılacak kimseler şeklinde değerlendirmeleri sebebiyle; kendilerini, perhiz kuralları ve diğer yasalarıyla onlardan her yönüyle farklı olduklarını hissettirmek isteyen İsraillilerin; her şeye rağmen, kendinden olmayanlara karşı bakış açısı, 'yaratılanları sevelim, onlara Tevrat'ı yaklaştıralım' (Bokser 1951;29) şeklinde özetlenen bir eğilimle açıklanabilir.

Tek tanrı inancının dayandığı veya zorunlu kıldığı, tüm insanları kapsayan evrensellik ideali, ile, seçilmiş halk olarak İsraillilerin övüldüğü ve bu tek tanrının dahi İsraillilerin tanrısı olarak adlandırıldığı ulus bilinci arasındaki çatışma, en açık bir şekilde, Yahve yasasının İsrailli olmayanlara karşı geliştirdiği tutumunda ${ }^{11}$ açığa çıkmaktadır. Ayrıca, İbrahim de, Eski Ahit'te, insanları kendi dinine çeviren ${ }^{12}$ bir kimse olarak anılmaktadır. Ayrıca, dininden dönerek kendileriyle bir kavım olan ve yeni bir insan haline gelen bu kimselerin kabulünde bir engel görülmemektedir. Yine, 'Rab, dürüstleri sever' (Bokser 1951; 36) ifadesiyle, yabancıları sevmeyi öğütleyen Eski Ahit'de pek çok paragrafa rastlamak mümkündür. Eski Ahit'in Aramı diliyle yazılan Midrash yorumlarında dürüstlügün önemini vurgulayan ifadelere ${ }^{13}$ rastlanılmıştır.

Yine Eski Ahit'de ve bununla ilgili yapılan yorumlarda ${ }^{14}$ doğruluk üzerine yapılan vurgulara sıç̧a rastlanılmakta, dürüstlüğün ve Tanrı sevgisinin yalnızca İsrail

\footnotetext{
11 "Tanrı buyurdu ki, onları yakınıma getirdim, reddetmedim, sen de böyle yap, eğer bir insan sana gelirse, katılmayı arzu etmişse, saf niyetiyle sizlere gelmişse, onu yakınına al, asla reddedip gönderme" (Kutsal Kitap, 2004; 749)

12 "Kız kardeşimizi sünnetli olmayan bir adama vermek, bu bize utanç olur. Ancak bu şartla size razı oluruz, bütün erkekleriniz sünnet edilip bizim gibi olursanız, o zaman kızlarımızı size veririz, kızlarınızı kendimize alırız, sizinle otururuz, bir kavim oluruz." (Kutsal Kitap, 2004; 649)

13 "Bir kimse, babası olamadığı için, çok arzu ettiği halde kahin ya da haham olamayabilir; ancak, soyunda yabancı ilahlara tapınan bulunsa dahi olsa, dürüst olmayı dilemişse, dürüstlerden olarak salihlerin arasına katılabilir, dürüstlük için soyun nereden geldiğinin hiç bir önemi yoktur.” (Bokser 1951; 36)

14 "İsrail dinine dışardan katılan bir kimse, Noachide yasaları diye bilinen bir dizi kabul ediliş aşamalarından geçmek zorunda bırakılmaktadır. Kesinlikle uyulması istenilen bu yasalar şöylece sıralanmaktadır; (1) yabancı ilahlara kesinlikle tapılmayacak, (2 ) Tanrının ismine karşı saygısızlıkta bulunulmayacak, (3) hiç kimseyi katletmeyecek, (4) zina yapılmayacak, nikâh düşmeyen akrabayla evlenilmeyecek, hiç cinsel sapıklık yapılmayacak, (5 ) hırsılık yapmayacak, yalan asla söylemeyecek, (6) mahkemelerle uygulanılan adalete tam olarak uyacak, ayinlerle ilgili emirlere ve gerekli görülen insancıl uyarılara tam bir bağlılık gösterecektir, (7) canlı bir hayvandan kesilen eti asla yemeyecek, arazide parçalanmış bir halde bulduğu eti yemeyecek, yiyeceklerle ilgili bütün yasalara da tam olarak uyacaktır, (8) sünnet olacak, eskiden kalma bütün geleneklerini terk edecektir" (Heschel 1956; 119)
} 
oğullarına has bir meziyet olmadı $\breve{g}_{1}^{15}$, gayet açıklıkla bildirilmektedir. Köle hayatıyla asırlar boyu zulme uğramış dahi olsalar, istilâ gören ülkelerinde haksızlığa boyun eğmiş dahi görünseler, İsrailliler, inandıkları bu tek Tanrının bütün insanları yaratan bir Tanrı olduğunu ve insanlığın soyunun Adem'de toplandığını kabul etmiş olduklarından, kendi dinlerine katılmak isteyenlere engel olunmuş da değildi. Nitekim, İsraillilerin dinine katılanların sayısının bir hayli fazla olması gerçeği göstermektedir ki; dürüstlüğün, içten samimi bir arzuyla istenmesi, dişardan gelen bir kimsenin kabulünde yeterli bir ön koşul olmakta, İsrail'in tek Tanrı düşüncesi, böylece çevresindeki herkesi etkilemektedir. İsrail'in tek Tanrı düşüncesini benimseyerek bu dine katılan bir kimsenin, bu inancın olduğu kadar İsrail ulusunun da bir üyesi haline geldiği gerçeği, burada çok önemli bir ayrıntıyı oluşturmaktadır. Daha açık bir deyimle, İsrail dini, ulusun dışındaki herkese açık olsa dahi, sonuçta bu dini benimsemiş olmakla, aynı zamanda, kişi, İsrail ulusundan biri haline gelmektedir.

Böyle bir kişi, kendi ulusal kimliğini terk ederek, İsrail'in bütün törensel geleneklerini yaşatmak ve dinsel yasalarına da bağlanmak zorundadır. Cumartesi yasağıyla, yiyecekle ilgili yortuları ve sıkıcı emirleriyle İsraillilerin geleneklerine tam olarak uymak zorunda kalacak olan bu kişi; bütün bunlardan başka, sünnetle ilgili meşakkâtli ayin törenlerine uymak durumundadır. Yahveizmin temeli ulus bilinci olduğu halde, bu ulus bilincine sahip olma gayretini gösteren bir yabancının dine dolayısıyla da ulusa katılımı engellenmiş değildir. Yabancı ilahlara tapmanın benimsettirdiği alışkanlıkları tümüyle terk eden, eski adetlerini yeminle reddeden bir kimse; cumartesi ve yortularla ilgili Sinagog'un törenlerine katılmakla ve bir İsrailli gibi yaşamaya başlamakla, İsraillilerin dinine giriş aşamasında bulunmaktadır. Noachide yasaları diye anılan bu emirlere tam olarak uyan bir kimse, İsraillilerin dünyasında kendine de bir yer bulacak dahi olsa; İsraillinin kânaatlerini ve inançlarını tam olarak paylaşmadığı ve yüreklilikle kendisini feda edemediği müddetçe, bu ulusun bir evlâdı olarak görülemeyeceği de, gayet açıktır.

\section{Ulusa Özgü Tanrı ve Yasası}

Dine dışardan katılanlarla ilgili hahamların öğretilerinden, Gentile dünyasına karşı oluşturulmuş olan bu genel ve kapsamlı tutumlarını haklı çıkaran pek çok fikirlere rastlanılmaktadır. Bütün her şey, Tanrı, niçin insanlığın tüm uluslarına yasayı vermemiştir de, yalnızca İsrail milletinden nebi seçmiştir, bu nedenle İsrail ulusu niçin diğer milletlerin üzerinde seçkin bir kavim ayrıcalığına Tanrı nezdinde ulaşmıştır vs., gibi sorularda düğümlenmektedir. Zira, Tanrının, yarattığı diğer ulusları hiçe sayarak, yalnızca İsraillilere yasalarını bildirmiş olması; İsrail geleneklerinin Tanrı buyruklarıyla barışmasına da neden olarak, diğer milletlerin bunları kabul etmesinde en büyük engel haline gelmesi; sadece İsrail'e seslenmesinin

\footnotetext{
15 "Haksız yere bana düşman olanlar, sevinmesin; sebepsiz yere benden nefret edenler, birbirlerine göz kırpmasın. Çünkü onlar, selâmet sözü söylemez, fakat ulusta uslu duranlara karşı hileli sözleri düşünürler. Tanrıdan her korkan, kutsanacaktır. Tanrı korkusu, irsi bir miras değildir; herkes Tanrı'yı sevebilir, Tanrı sevgisiyle de dürüstlerden olabilir. Bundan dolayı, Tanrı, dürüstleri sever” (Kutsal Kitap, 2004; 932 )
} 
sonuçlarının ne ölçüde yararlı olduğunun irdelenmesine yol açmıştır. Eski Ahit'de ${ }^{16}$ Tanrı yasasının yalnızca İsrail nesline emanet edilmiş olması, doğrudan bu ulusun onuruna bağlanılmıştır. Ancak, bütün insanları yaratan Tanrının hidayet yolunu yalnızca İsraillilere bildirmesi, diğer ulusları sırf bu nedenle Kendine düşman olarak görmesi gerçeği; İsrail neslinin asaletinin dışında, yine de inandırıcı bir açıklamasının yapılmasını gerektirmektedir. Destanımsı açıklamalarla, Tanrı yasasının her bir ulusa tek tek sırayla sunulduğunu, ancak, İsrail dışında bunlardan hiç birinin Yasayı kabul etmeye yanaşmadıkları övgüyle söz edilmektedir. Kısaca Noachide buyrukları olarak özümsenen bu Tanrı Yasasını hiç bir ulusun kabule yanaşmamış olması, yorumlarla dikkâtle işlenmiş ve özenle genişletilmiş olan bu Yasanın diğer milletlerce kabulünü ummak da, sonradan, yararsız olduğu kadar nafile bir gayret olarak da görülmüştür.

Eski Ahit yorumlar ${ }^{17}$, yasayı kabul eden tek kavmin İsrail oğlunun olduğunu vurgulamaktadır. Eski Ahit'deki ifadeyle ${ }^{18}$, İsraillilere çölde verilmiş olan bu Yasa, hiç bir ulusa özel olarak ait kılınmamış, hangi milletten olursa olsun herkesin sahiplenebileceği bir yolu ifade ederek; yasayı kabul edip uygulayana yasa emanet ${ }^{19}$ edilmiştir. Bu destanımsı ifadelerden de gayet açıklıkla anlaşılacağı gibi, İsrail'de tek Tanrı inancı, diğer uluslara kapalı bir ayrıcalık değildir; herkes bu inanca sahip olabilir, ancak, Tanrı Yasası, yalnızca İsrail oğullarından İshak nesli tarafından kabul edilmiştir. Yine de ulusal ve dinsel ön yargılar dolayısıyla, yarattığı bütün insanlar arasında tamamiyla tarafsız olan, birini diğerine yeğlemeyen ve asla da cephe almamış olan kusursuz bir tek Tanrı kavramının İsraillilerce geliştirilmiş olduğunu söylemek, çok güçtür. Gerçi İsrail ülkesi ilahlara tapınan Romalılar tarafından istilâ edilmiştir, İsrail'in kutsal kitaplardaki saygınlığı uğradığı zulüm ve haksızlıklarla ayaklar altında çiğnenmektedir; bunca baskı ortamına karşı beşeri bir reaksiyon olarak, İsrailli onları, Tanrı'yı reddeden günahkâr kimseler olarak görmektedir.

\footnotetext{
16 "Kelamını Yakub'a, kanunlarını ve hükümlerini İsrail'e bildirir. Hiç bir millete böyle etmedi ve onlar hükümlerini bilmedi. Rab'be hamd edin" (Kutsal Kitap, 2004; 461)

17 “Tanrı Kendisini Esau'nun çocuklarına ilham yolu ile tanıttı, 'Yasayı alacak mısınız' diye sorunca, 'içinde neler yazılı' diye karşılık verdiler; Tanrı da 'asla öldürmeyeceksin' diye yanıt verince, babalarımızdan bizlere miras olarak kalan bir söz var 'kılıcınla yaşayacaksın' denilmektedir, şimdi biz bundan nasıl vazgeçeceğiz, dediler. Yine Tanrı, Ammon'un çocuklarına emrini içeren Yasasını anlattı, onlara, 'asla zina etmeyeceksiniz' derken; Ishmael nesline de 'kesinlikle çalmayacaksın, kendine gelmeyeni sahiplenmeyeceksin, harama asla el uzatmayacaksın' diye bildirince, bunlardan her biri, aynı nedenlerden dolayı, Tanrının Yasasını almaya yanaşmadı." (Kohler 1956; 37)

18 "Sizi nası1 Kendime getirdim gördünüz. Şimdi, eğer gerçekten sözümü dinleyecek ve ahdimi tutacaksanız, bana bütün kavimlerden has bir kavim olacaksınız; çünkü, bütün dünya benimdir, siz Bana kâhinler melek-tu ve mukaddes bir millet olacaksınız" (Kutsal Kitap, 2004; 964 )

19 "Tanrının en son hükmü, batıl inançlarından vazgeçerek davetine ve yoluna katılan her bir kimseyi huzurunda görmek istediği için; tüm uluslar bu yargının kapsamı içinde yer almaktadır. Tanrı, sapkınlıklarında ısrar edenlere, 'niçin Beni reddediyorsunuz ve gerçekte var olmadıkları halde niçin yabancı ilahlara tapıyor ve hizmet ediyorsunuz' diye sorunca; bu insanlar, 'dünyanın yaratıcısı ve var olan her şeyin tek sahibi, eğer biz Senin kapından girmeyi istersek, bizi kabul edecek misin' diye yakarmaya başladılar. Tanrı bu sözleri işittiğinde, 'sapkınlıklarından dönenleri ve yoluma katılanları bırakın gelsinler, onlar, kendi işlemekte oldukları dalâletlerine karşı yine kendileri tanıklık etmektedirler." (Kutsal Kitap, 2004; 582 )
} 
Tanrı, Kendi davetini kabul eden İsrail halkının uğradığı zulümlerden haberdar olarak, güçsüzlüklerini de çok iyi bilerek; sonunda, seçtiği bu kavme haksızlık ve zulüm edenlere karşı Kendi gücünü göstereceği günleri de gelecektir. Tüm evrenin ve yaşayan her insanın tek yaratıcısı olduğuna inanılan bu tek Tanrının, Kendi yarattı̆̆ insanların bir kısmına karşı böyle bir öç alma duygusunu beslemekte ${ }^{20}$ olması; yetersiz olduğu kadar yanlış da kabul edilen bir evrenselliğe götürdüğü gibi, tek bir ulusu seçerek üstün kıldığı duygusu, Tanrının bütün insanları eşit yarattığı düşüncesine de aykırı gelmektedir. Oysa, Tanrının daveti, Eski Ahit metinlerinden de açıkça fark edilebileceği gibi, tüm uluslara açık olduğundan; tek Tanrıcılığın esasını, Tanrı'ya teslim olma ve yalnız O'na yönelme, bu ibadetin ön koşulu olarak da ahlâkın en yalın ve en geniş kurallarına bağlı kalma, böylece de, gelecekteki yaşamı için ve kurtuluşu için uygun bir geçiş iznini alabilme gibi kişilik özellikleri oluşturmaktadır. Bu kişilik özelliklerine sahip olan ve sadık kalan herkes ${ }^{21}$, hangi ulustan olursa olsun, Tanrı yoluna katılabilir.

İkinci tapınağın açıldığı günler boyunca, Tanrının, giderek çok daha fazla bir şekilde, üstün ve temiz olduğuna inanılmaya başlanmış; Tanrının bu kutsallığı nedeniyle, ancak melekleri vasıtasıyla kelamının ulaşabileceği fikri ${ }^{22}$ çok yaygınlık kazanmıştır. Şayet Tanrı yolunu ahlâki erdemler, ruhani saflık ve yönelme aşkı gibi davranışsal özellikler oluşturmuşsa, kurtuluşa giden yol bunları gerektirmekteyse; İsrail ulusunun seçkinliğine ve üstünlüğüne dayandırılmak istenilen bu tek Tanrı inancının yetersizliği ve de yanlışlığı gayet açık bir hal alacaktır demektir. İsraillilerin fikirlerinin yalınlığını ve genişliğini göstermek için, üçüncü asırda çok yaygın olan, 'yabancı ilahlara tapmaktan sakınan bir kimse, mutlaka Ísraillidir'

\footnotetext{
20 “İsraillilerin, diğer uluslardan söz ederken, bunların yabancı ilahlara tapınma adetlerinden, gerçekten de çok samimi bir şekilde nefret ve öfkeyle söz etmekte olmaları, her türlü ahlâksızlık ile haksızlıklarının tek sebebinin yabancı ilahlara tapınmalarından kaynaklandığını öne sürmeleri, çok dikkât çekicidir. Her türlü kötülüğün kaynağı, yabancı ilahlara tapınma âdetleri olunca; İsraillilerin tek Tanrı inancı ve buna dayalı olarak kurulan ahlâk anlayışı, yabancı ilahlardan bütünüyle ayrılan ve bu tür âdetleri de Tanrı tarafindan asla affolunmayacak günahlar olarak gören bir eğilimi de beraberinde getirmiştir. Artık bu noktadan sonra, kendilerine zulmeden Misırlılardan veya Romalılardan nefret etmek, yabancı ilahlardan da nefret etmekle özdeşleşmiş olduğundan; Tanrının, onları cezalandıracağını beklemek, kendilerine seçkin bir ulus olarak seslenmiș olduğuna inanmak, her bir İsraillinin âdeta manevi bir güç kaynağı haline gelmiştir.” (Kohler 1956; 48)

21 “Tanrı, İbrahim, Musa, Davud, Süleyman vs., gibi nebileri vasitasıyla İsrail oğullarıyla doğrudan ve gönülden bir bağlantı kurmuş; açıkça bildirdiği sözleriyle de, buyruklarını, aslında bütün Adem nesline duyurmuştur. Buna göre, Tanrı hükmü, kesindir ve âdildir; Tanrı ödüllendirdiği gibi, cezalandırmaktadır da. Yine, Tanrının adaleti, acıma ve merhametiyle, her şeyin üzerindedir. Günahlarından dolayı pişmanlık duyup Kendisine yönelen herkesi kabul eder; kişi, Ona yavaş yavaş ve güçlükle yönelmiş olsa dahi, Tanrı bu kimseye koşarak gelir, kendisinin asla varamayacağı bir yerde Tanrı onu karşılar, Tanrının tövbekâr günahkârı karşılayışı ve benimseyişiyle ilgili, pek çok Rabbinik anlatımlar bulunmaktadır. Denilebilir ki, Tanrı yolu bütün uluslardan gelen herkese açıktır, ancak, bu yoldan giden ve yasasını kabul eden tek ulusun İsrail nesli olduğuna inanıldığı için; Tanrı, İsrail ulusuyla nebileri vasıtasıyla doğrudan gönülden bir bağlantı içine girmiştir.” (Kohler 1956; 52 )

22 "Artık, Tanrı, seçtiği nebisine doğrudan seslenmemekte, görevlendirdiği bir melek vasıtasıyla buyruklarını bildirmektedir. Tanrının habercisi olarak melek kültünün gelişmesi, dünyaya inerek Tanrı buyruğunu bildirmekle görevlendirilmiş olduğu düşüncesi; aşırı kuramsal üstünlüğün ve gerçek dünyayla dinsel anlamda mesafeliliğinin bir işareti gibi görülmüştür. Vahiye ait dinsel bir dönem böylece başlamış olarak, başlangıcından sonuna kadar hangisinin vahiy, hangisinin ise vehim olduğunu birbirinden ayırmak; mucizelerin kanıtlı̆̆ıla, yani alametin aranmasıyla kabul edilir olmuştur. Hiç kuşkusuz, İsraillilerde tek Tanrı inancı ortaya çıktığı andan itibaren melek düşüncesinin olmasına, şeytanın insanı ayartan bir düşman olarak kabul edilmesine rağmen; yeni olan bir şey vardı, o ana kadar Tanrı ile insan arasında meleğin aracılık işlevini üstlendiği, Tanrının emirlerini veya sözlerini nebiye bildirme gibi görevlerinin olduğundan nadiren söz edilmişti.” (Steinberg 1953; 84)
} 
(Bokser 1951; 63) atasözü, Tanrının İsrail ulusunu seçmiş olduğu inancının yansımasından başka bir anlamı taşımamaktadır. İşte, tüm dünyanın ulusları, çoktanrıcı âdetleriyle ahlâksızlığa ve azgınlığa sürüklenmiş bir haldeyken, İsraillilerin tek Tanrı inancının gerektirdiği ahlâki erdemlerini korumak istemesi; Tanrının İsrail ile doğrudan bir bağlantı kurmasına yol açmıştır. Yabancı ilahlara tapınmanın Tanrı tarafından cezalandırılması kadar, dünyadaki bütün bu ulusların, diğer bütün ilahlarını terk ederek ve istemlerini sapıklık olarak görerek, İsrail'in bu tek Tanrısını kabul etmeleri ve yalnızca Ona tapınmaları, İsraillilerin en büyük dileği haline gelmiştir.

Oysa, Rabbinik döneminde, artık meleklerin bu vahiy bildirici görevi dikkât çekici bir hale gelmişti. Halbuki, çok değil, bundan yalnızca bir asır kadar önce, sadece Tanrıdan söz edilmekte; Tanrının insanla konuşmakta olduğu ve gördüğü, kalplerinin en gizli niyetlerine vukuf olduğu, tövbe edenlere şefkâtle yaklaştığı, zor durumda olana anında yardım ettiği, nebisiyle doğrudan konuştuğu ve kalbine seslendiği anlatılmaktaydı. Eğer Tanrı, insanla doğrudan konuşmuşsa, onu dinlemekte ve gözetmekteyse, bir an dahi uyku tutmamakta ve yarattı̆̆ bütün insanlardan haberdar olmak Ona ağır gelmemekteyse; her hangi bir meleğe de bu doğrudan bağlantıda hiç bir görevin verilmemiş olması gerekirdi. Melekler, ikincil derecedeydi; Tanrı ile insan arasında her hangi bir aracılık işlevini üstlenmiş değillerdi; Tanrı, buyruğunu ve kelamını, seçtiği nebisine, doğrudan Kendisi zaten bildirmekteydi. Kaldı ki, nebi olsun olmasın, Tanrı'ya inanan her insan, zaten Tanrıyla gönüldaştılar ve çok samimi yoldaştılar, Tanrı güvenilir tek dost ve tek arkadaştı. Bütün insanları yaratan Tanrı, Kendisine inanmakla ruhunu arındıran ve ahlâki erdemlere sahip olan herkesle; zaten doğrudan konuşmakta, halini bilmekte, onunla çok samimi bir arkadaş olmaktaydı. Tanrı ile İsrailli, nebiye doğrudan bildirilen ve sunulan yasası sayesinde, zaten sarsılmaz bir inanç ve dostluk birliğini kurmuştu. Nebisine doğrudan bildirdiği Yasası, Tanrının apaçık bir lütfu ve ihsanıydı.

Nitekim, Eski Ahit'deki bazı ifadeler ${ }^{23}$, Tanrının nebisiyle doğrudan konuştuğu, onu duyduğu ve Yasa yoluyla insanlarla bağlantı kurduğu anlamını içermektedir. Böylece, İsraillilerin inançlarında, birbirine aykırı olarak gelişen kuşkulu eğilimler yer etmeye başlamıştır. Vahiy yazıcıları, Tanrı buyruklarının melekler vasıtasıyla nebilere ulaştığını iddia ederlerken; eskinin bilgisiyle yol almış hahamları ise, Tanrının doğrudan insanla konuştuğunu, Kendisine yönelen kişiyi daima duyduğunu, kişinin de Tanrı kelamını kendi kalbinde hissedebileceğini öne sürmüşlerdir. Gerçekte, ne vahiy bildiren meleği bu görevi esnasında bir gören olmuştu, ne de

23 “Abram, Rabbin kendisine söylediği gibi gitti; Rab, Abram'a görünüp dedi; Rab, Musa'ya söyleyip dedi; Musa, Rab'bin kendisine emrettiği gibi yaptı. Rab, Musa'ya ve Harun'a söyleyip dedi; Rab, Musa'nın hizmetçisi Nun oğlu yeşua'ya söyleyip dedi. Yeşuu'nun ölümünden sonra vaki oldu ki, İsrail oğulları Rabbe sorup dediler, rab dedi ki; İsrail oğulları, Rab'e feryad edince, Rab onlar için bir kurtarıcı çıkardı; Rab yine göründü, çünkü Rab, Samuel'e de Kendi kelamiyla izhar etti. Davud, Rab'den sordu, Rab Davud'a dedi, Davud o gün Rab'den korkup dedi, Davud şu ilâhinin sözlerini Rabb'e söyledi, Tanrının yolu kamildir sözü saftır, Rabbin Ruhu benim vasıtamla söyledi, sözü benim dilim üzerinde idi. Rab, Süleyman'a söylediği gibi ona hikmet verdi, Rab söylediği sözünü tamam etmiştir, Rab'bin vaat ettiği gibi İsrail tahtında oturuyorum. Rab, ona dedi, önümde yaptığın duayı ve yakarışı işittim, ismimi ebediyen oraya koymak için yaptığın bu evi takdis ettim, gözlerim ve yüreğim daima orada olacaktır." (Kutsal Kitap, 2004; 691) 
Tanrı'ya içten yönelerek kalbinde Tanrının sesini hissettiğini söyleyen nebinin ikna edici bir delili bulunmaktaydı. Her iki halde de kişiyi haklı kılan, bir ölçüde de deli olmadığına herkesi ikna ettiren, en önemli özelliği, bu durumda, alamet göstermesi olmaktaydi.

\section{Kendini Bir Ulusla Sınırlayan Tanrının Adaleti ve Merhameti}

Tanrının insanla doğrudan bağlantı kurduğunu ${ }^{24}$, meleklerin kelâmı taşıyan aracılık işlevinin olmadığını savunan bazı İsrailli din bilginleri; Tanrı ile insan arasında hiç bir aracının olmadığında ısrar ederken, eğer bir vasıta aranacaksa, bunun şu ya da bu melek değil, doğrudan Tanrı tarafindan bildirilmiş olan Yasa olduğunu söylemektedirler. Kaldı ki, Tanrı, işitme ve konuşma nitelikleriyle, insanlara ne yapmasını bildiren emirlerini anlatmak için, asla bir meleğe gereksinim duymamaktaydı. Tanrının insanla aracısız konuştuğunu içeren inançlarına delil olarak, 'sen, hikmet ruhu ile doldurduğun bütün yüreği, hikmetlilere söyleyeceksin' (Kutsal Kitap, 2004; 953) ifadesini göstermektedir. Eğer Tanr1, Kendisine her sesleneni işitmekte, onun tövbesinden ve nedametinden haberdar olmaktaysa, doğrudan bu kişinin kalbinde seslenmekteyse; nebisiyle doğrudan konuşmuşsa, Yasası böylece oluşmuşsa; Tanrı ile insan arasında hiç bir aracı da bulunmamakta, meleklerin aracılığına dayanan vahiy anlayışı da tümüyle reddedilmekteydi. Nitekim Eski Ahit’teki bir ifade ${ }^{25}$, Tanrının nebisine emirlerini doğrudan bildirmekte olduğunu kanıtlar niteliktedir.

Tanrının insanla doğrudan söyleşisi ve yakın arkadaşlığ ${ }_{1}^{26}$, özellikle de Tanrı dürüstlüğünü ve adaletini hiç durmaksızın yineleyen, merhamet ve lütfunun yanı sıra

\footnotetext{
24 "Bebek taşıyan anneler, çölde yolunu arayan düşkünler, haksızlıkla hapse düşmüş kimsesizler, doğuda veya batıda da olsalar, güneyde veya kuzeyde de bulunsalar, Tanrı, onların yakarışlarını duyar" (Bokser 1951; 81)

25 "Musa döndü, şahadetin iki levhası elinde olarak dağdan indi; levhaların iki tarafı yazılıydı, bir yüzü ve öbür yüzü yazılıydı. Levhalar, Tanrının işiydiler, levhalar üzerine oyulmuş yazı Tanrı yazısı idi.” (Kutsal Kitap, 2004; 259)

26 “Tanrının merhametinin ve şefkâtle tüm insanlara yaklaşmasının, daima, adaletinin üzerinde olduğunu; ancak, Tanrı affının sonsuz olduğu, nedamet içinde tövbe dileğinin affedileceği umudunun gerçekliliği, İsraillileri ahlâğa uygun olmayan aşırılıklara ortam hazırlamamıştır. Kudüs'ün M.S. 1. yüzyılın içinde düşmesiyle başlayan feci olaylar arasında tapınağın yıkılması gibi korkunç sonlardan hiç biri; İsraillilerde, Tanrının iyilik ve merhametine yönelik kânaatlerin yıkılmasına neden olmamıştır. Tam tersine, bu kötü günlere, içlerindeki günahkârların neden olduğuna inanılarak; Tanrının İsrail oğullarını uyarmakta olduğu düşüncesi, herkes tarafından rağbet bulmuştur. Böylece, Tanrının adaleti ile merhameti arasında bir zıtlığın bulunduğunu, tam bir açıklıkla öne sürülmüștür. Dinsel öğretinin geliștirdiği Rabbinik çalışmaları boyunca, bu bilinç giderek çok daha keskin bir hal almış, Tanrının Kendisiyle ilgili üstün aklın mantığını açığa çıkartan bir uyumun olması gerektiğine inanılmış, Tanrı doğasının adalet ve merhamet olmak üzere bu iki temel görünümü arasındaki bağıntı irdelenmiştir." (Friedlander 1937; 117 ).

26 “Tanrının merhametinin ve şefkâtle tüm insanlara yaklaşmasının, daima, adaletinin üzerinde olduğunu; ancak, Tanrı affının sonsuz olduğu, nedamet içinde tövbe dileğinin affedileceği umudunun gerçekliliği, İsraillileri ahlâğa uygun olmayan aşırılıklara ortam hazırlamamıştır. Kudüs'ün M.S. 1. yüzyılın içinde düşmesiyle başlayan feci olaylar arasında tapınağın yıkılması gibi korkunç sonlardan hiç biri; İsraillilerde, Tanrının iyilik ve merhametine yönelik kânaatlerin yıkılmasına neden olmamıştır. Tam tersine, bu kötü günlere, içlerindeki günahkârların neden olduğuna inanılarak; Tanrının İsrail oğullarını uyarmakta olduğu düşüncesi, herkes tarafından rağbet bulmuştur. Böylece, Tanrının adaleti ile merhameti arasında bir zıtlığın bulunduğunu, tam bir açıklıkla öne sürülmüştür. Dinsel öğretinin geliştirdiği Rabbinik çalışmaları boyunca, bu bilinç giderek çok daha keskin bir hal almış, Tanrının Kendisiyle ilgili üstün aklın mantığını açığa çıkartan bir uyumun olması gerektiğine
} 
sevgisiyle şefkât gösterdiğini açığa çıkaran ilâhiler (mezmurlar). örnek olarak gösterilmektedir. Tanrı, nebisiyle doğrudan konuşmakta, yarattığı her bir insanın niyazını işitmekte, Kendisine tövbeyle yönelen kişiye de kalbinde doğrudan seslenmekte olduğundan; meleğin aracılığını reddetmiş olmakla, eski inançlarında ısrar eden bir kısım İsrailliler, bir bütün olarak da vahiy olgusunu da kabul etmemişlerdir. Tanrının adalet ile merhameti, öne sürülen aykırılıklara rağmen, insanlığın devamlılığı uğruna gerekli görülmüştür. Rabbinik literatüründe yer alan, tarihi belirsiz, Midrash yorumu, adalet ile merhametle ilgili İsraillilerin Tanrı yorumunu $^{27}$ açıklar niteliktedir. Böylece Tanrı, hem adaletiyle ve hem de merhametiyle insanlara hükmetmektedir. Yabancı ilahlara taparak ahlâksızca âdetler edinen, İsrail ülkesini istilâ ederek gaddarca haksılılılar ve zulümler yapan diğer uluslardan Tanrının nefret etmiş olması; ayrıca, hiddetli ve kinci bir Tanrı anlayışıyla inananları bilinçlendiren Eski Ahit'in karşı konulamaz bunaltıcı hükmü nedeniyle; İsrail'in tek Tanrı eğilimi, ilahi bir karakter kattıkları ahlâki değerlendirmelerinin kusursuz olmasını sağlayamamıştır.

Noachide yasaları diye bilinen, kişinin İsrailli olup olmadığını sınayan nitelikleri edindiği halde, diğer uluslardan gelmiş olması nedeniyle; bir kimsenin, günahlarından dolayı ne kadar nedamet duyup içten tövbe dilemiş dahi olsa, sırf İsrailli olmadığı için, ulusal sayıldığı ölçüde kusurlu kılınan bu tek Tanrı anlayışları yüzünden önemsenmeme haliyle karşılaşması çok büyük bir ihtimaldir. Oysa, bütün insanları ve var olan her şeyi yarattığına inanılan, ancak uluslaştırılmış olduğu ölçüde diğer uluslardan da soyutlanmak istenilen İsrail'in bu tek Tanrısı; yabanc1 ilahlara tapınma âdetlerini yaşatmış olsa da, azgınlıklar yaparak ahlâka uymayan kepazeliklerini gösterse de, zalimce ve haksızca davranmış dahi olsa, sadece ve sadece İsrail kavminden geldiği için, hâlâ, kabul edilebilir ve yararlı kılınabilir görülerek, böyle bir kimseden asla vazgeçilmemektedir. Bu nedenle, Tanrının asla kuşku duyulmayan daha fazla merhametliliği, babacanlığı, cana yakın hoş sohbetliliği, hep İsrail kavmi sınırlarınca değerlendirilmiştir.

Neredeyse, kıskanç bir Tanrı, Kendine, kıskanç bir ulus yaratmış; yabancı ilahlara tapınma âdetleri yüzünden ahlâki meziyetlerini kaybederek sapkınlık yapan, haksızlıklara ve zulümlere kapılmaktan kendini tutamayan İsrailli bir kimse; Tanrının istemediği bu halleri yüzünden, dinden çıkarılma ya da kavmin üyesi sayılmama gibi bir cezai yaptırımla karşılaşmış değildir. Böyle bir kimsenin İsrailli kaldığına ne kadar inanılmışsa; Kudüs'ün yerle bir edilmesi ve tapınağın yıkılmasıyla ilgili feci olaylara, Hadriyanik isyanlara Tanrının hiç karşı koymamış olmasına da o kadar önemsenmemiştir. Tanrı, günahkârlar yüzünden öfkelenmiş ve gazabını da bu

inanılmış, Tanrı doğasının adalet ve merhamet olmak üzere bu iki temel görünümü arasındaki bağıntı irdelenmiştir." (Friedlander 1937; 117 )

27 "Tıpkı, boş bir kadehe sıcak suyu dökersem kadeh çatlar veya sadece soğuk su doldurduğumda da kadeh büzülür, diyen bir kralın, soğuksu ile sıcak suyu birbirine karıştırıp, boşaltmasıyla kadehe hiç bir zarar vermemesi gibi; Tanrı da demektedir ki, bu dünyayı yalnızca ve her yönüyle merhametimle yaratmış olsaydım, günahları daha da arttırmış olacaktım; eğer sadece adaletimle hükmetmiş bulunsaydım, dünya buna nasıl tahammül edecekti? Bu nedenle dünyayı, adaletimle ve merhametimle birlikte yarattım, bu ancak Benim katlanabileceğim bir haldir." (Bokser 1951; 107) 
şekilde göstermiştir ${ }^{28}$. Yine de, şiddetli 1stıraplara ve yıkımlara uğranıldı̆̆ı günlerin başlangıcında, ilahilerde göz yaşları dökülmüş; ' bu üzüntülü günler, daha ne kadar sürecek? Tanrının merhametini gösterip acıdı̆̆l gün ne zaman gelecek? Bu ceza, bizim sapkınlıklarımız yüzünden geldi' (Bokser 1951; 96 ). gibi, yakınmalarda bulunulmuştur. $\mathrm{Bu}$ halleriyle, Gentile'li gibi davranan İsraillilerin yüzünden tüm ulusun cezalandırılmış olduğuna inanılmakla birlikte; içlerinde Tanrının sevdiği insanların, bu dünya içinde mutlaka saadete erdirileceği günlerin kesinlikle geleceğinde 1srar edilmiştir. Gelecekteki mutlu ve zaferli günleri, Tanrı, bu fesat döneminde emirlerinden ayrılmayıp Kendisine yönelen kișiler hürmetine ${ }^{29}$, yaratacaktır. Nefretle inleyen bir kalp, mayanın hamura işlediği gibi; kötü günlerden sorumlu tutulan bu sapkın İsrallilerin zihinleri üzerinde tesirli olmakta, onları tekrar dinlerine dönmeye ve yasaya uymaya zorlamaktadır. $\mathrm{Bu}$ gibi felâket günlerinde, Tanrı, merhametli ve acıma eğilimini göstermek yerine, katı yüreklilikle yalanın karşılığını vererek adaletini uygulamada 1srarlı olduğu için; artık, üzüntüyle tövbe dilemenin veya kefaretinin ödenilerek sıkıntıdan kurtulmak istemenin, hiç bir yararı yoktur.

Yasaya uyan İsrailliye ise, sevgisi çok büyük, merhameti de sonsuzdur. Dua kitabında, "Babamı, merhameti ve şefkâti çok büyük olan Babamı, sevgisiyle Ísrailliyi Kendi halkı olarak seçti" (Bokser 1951; 42 ). şeklinde Tanrının anılmış olması, yarattığı diğer insanlarla bu sevgiden pek bir pay verilmediğini kanıtlar gibidir. Eski Ahit'de kayıt altına alınan, İsraillilerin karşılaşmış oldukları olayların mantıki değerlendirilmesi yapıldığında; İsrailliye odaklaşmış olan bu ilâhi sevginin, Yasaya uyulmasıyla cezaya dönüşmeyeceğini garanti etmektedir. Böylece, Romalı general Titus tarafından yerine getirilen dehşetli ve korkunç istilâ anlarında, Tanrının adaletsizliğinden veya güçsüzlüğünden söz edilmemekte; tam tersine, bu kuvvetlerin Tanrı tarafindan kullanıldığına inanılmaktadır. İsraillilerin günaha düşmelerinin, yasayı hiçe saymalarının ve azgınlıklarının bir sonucu olarak, Tanrının öfkesini fazlasıyla hak etmişlerdir, ölümden de beter olan bu cezaya

\footnotetext{
28 “İsraillilerin ulus dini anlayışları ile uğradıkları felâketler, ne dereceye kadar, Tanrının insanla ve insanın da Tanrıyla bağlantı kurmakta olduğu inancına tesir edebilir, bu, gerçekten irdelenmesi gereken bir ayrıntıdır. Bütün İsrailli dindarlarının üzerinde uzlaşıya vardıkları sonuç, ulus içindeki bu sapkın kimselerin âdetlerinin ve ahlâki bozukluklarının giderilmesi, bu kimselerin ulustan atılmaları yerine Tanrı emirlerine uymalarının sağlanması için, bu felâketlerin Tanrıdan gelen bir uyarı olduğuna inanılmış, sürekli olmayan hal olduğu kabul edilmiştir. Tanrıyla ilgili, acıma ve merhamet gösterme, adaletini mutlaka günün birinde uygulama, Kendisine yakaran İsrailliyi işitip affetme, seçtiği bu ulusun evlâtlarına sevgiyle yaklaşma gibi fikirlerini; böyle günlerde, sapkınlıklarında aşırı giden bazı İsraillileri hizaya getirtmek için layık gördüğünü belirterek, daha da 1srarlı bir șekilde geliştirmişlerdir. Bu tür felâketlerin gelip geçici, Tanrı merhameti ile adaletinin ise, İsrailli için kalıcı olduğunu savunmuşlardır." (Roth 1974; 88-89)

29 "İsraillinin Tanrısıyla kuracağı bağlantısı, Tanrının nebilerine doğrudan bildirmiş olduğu Yasası yoluyla yalnızca Tanrıdan korkulması gerektiği düşüncesini pekiştirmiştir. Seçtiği İsrail halkının daima yanında olduğunu, her firsatta açıklıkla belirtmek suretiyle, Tanrı, İsraillinin haklı olduğu duygusunu, bir ölçüde gereksiz bir şekilde beslemiştir. İsrailli, Tanrı tarafından seçilmiştir ve haklı kılınmıştır duygusu; İsrailli olmakla, seçilmiş bulunması özdeş kılınmıştır. Tanrının korkutucu ve uyarıcı tehditlerde bulunma eğilimini hiç bir zaman kaybetmemiş olması; İsraillinin Tanrı'yı sevdiği ölçüde korkmasına da yol açmıştır. Amidah duasının, 'büyüksün, kudretlisin, heybetlisin' sözleriyle açılması; Tanrıdan korkulması ve sevilmesi gerektiğinin üzerinde önemle durulmuş olması, bir tesadüf değildir. Emirlerine uymayanlar için, korkutucu ve uyarıcı bir güç halinde algılanan Tanrı; Yasasına uyanlara ise, sevgi ve şefkâtle yaklaşmakta, onlara karşılıksız dostluğunu sunmaktadır." (Jacobs 1998; 36 )
} 
uğratılmışlardır. Nitekim İsa da Yeni Ahit'teki bir ifadede ${ }^{30}$, insanın ruhuna ve bedenine hakim olan Tanrıdan korkulması gerektiğini belirtmiştir. Benzer şekilde, kendisini ziyarete geldikleri bir sırada, sürekli ağlar bir halde buldukları, Zaccai'ye, müritleri neden ağladığını sorduklarında, verdiği yanıt, İsa'nın her şeye kadir olarak gördüğü Tanrı korkusunun önemini vurgular ${ }^{31}$ niteliktedir. İnanç, Tanrı korkusunu zorunlu kılmıştır.

Elbette, Tanrının adaletinden olduğu kadar, İsrail'e yönelik beslediği sevgisinden de asla kuşku duyulmamaktadır. Kudüs'ün istilâya uğraması ve tapınağın yıkılması gibi feci günlere; İsraillilerin günahları sebep olmuş, Tanrı tarafından böylece cezalandırılmışlardı. Cezanın veya ödülün bu dünyada $\mathrm{m} 1$ verileceği, yoksa, gelecekteki yaşamın sırf bu maksatla $\mathrm{m} 1$ yaratılmış olacağı, daima, İsrailli din bilginlerini birbirlerine düşüren konular arasında yer almıştır. Pek çok İsrailli, öbür dünyada nelerin olup biteceğini bir ölçüde dikkâte almadığından, ölümden de pek korkmamaktadır. Oysa, beklenildiğinin tam tersine, İsrailli elem verici 1stırabı, katlanılamayacak güçleri, şehitliği ve zulmü bu dünyada görmüştü. Şiddetli cezalara da bu dünyada uğramış olduklarından, elbette, gelecekteki yaşamda sonsuz saadete layık görülecekler, yine kendileri olacaktı. $\mathrm{Bu}$ nedenle, ulusların zulüm ve haksızlıkları, yıkım ve tahribatları; yalnızca Tanrı adaletinin birer tezahürleri değil, fakat aynı zamanda, onları yasaya uymaya zorlayan sevgisinin de birer sonucuydu. Rabbinik yazın içinde, Süleyman'ın hikmeti gerçekten çok önemli bir yer tutar. Süleyman'ın sözleri ${ }^{32}$ Tanrı cezasının, kötülükten ayrılma yönünde bir uyarı olduğu ve iyiliklere zorladığı gibi anlamları taşımaktadır. Ancak, Tanrı yasasının yorumu,

\footnotetext{
30 "Siz dostlarıma diyorum, bedeni öldürüp de ondan sonra başka bir şeyi yapmaya kadir olmayanlardan korkmayın. Fakat kimden korkacağınızı size göstereyim; öldürdükten sonra cehenneme atmaya kadir olandan korkun, evet size derim Ondan korkun" (Kutsal Kitap, 2004; 1485)

31 "Bu gün diri olduğu halde, yarın mezara girip eti de kanı da çürüyecek olan bir kralın önüne beni getirecek olsalar, bana öfke içinde kızmış ve hiddetle hüküm verecek olan bu kralın gazabı ebedi olmadığı ve taktığı bağları da bu dünyaya ait olduğu halde, beni öldürecek olsa, bunun sonsuz ölüme yol açmayacağını bildiğim halde, para teklif ederek veya etkili sözleri söyleyerek, kendisini yumuşatabilirim. Ancak, beni kralların kralı olan Tanrının huzuruna getirmiş olsalar, öfkesinin ezeli ve hükmünün daimi olduğu bu Tanrıdan, şimdiden korkmayayım mı? Paranın, ananın ve babanın bir hayrı olmadığı o gün için, şimdiden, endișeyle göz yaşı dökmeyeyim mi? Tanrının o hüküm anında, önünde, cennete ya da cehenneme gidecek yoldan birine gireceğimi, bu günden bildiğim halde, şimdiden Tanrıya yakarmayayım mı?" (Blau 1959; 53 )

31 "Bu gün diri olduğu halde, yarın mezara girip eti de kanı da çürüyecek olan bir kralın önüne beni getirecek olsalar, bana öfke içinde kızmış ve hiddetle hüküm verecek olan bu kralın gazabı ebedi olmadığı ve taktığı bağları da bu dünyaya ait olduğu halde, beni öldürecek olsa, bunun sonsuz ölüme yol açmayacağını bildiğim halde, para teklif ederek veya etkili sözleri söyleyerek, kendisini yumuşatabilirim. Ancak, beni kralların kralı olan Tanrının huzuruna getirmis olsalar, öfkesinin ezeli ve hükmünün daimi olduğu bu Tanrıdan, șimdiden korkmayayım mı? Paranın, ananın ve babanın bir hayrı olmadığı o gün için, şimdiden, endişeyle göz yaşı dökmeyeyim mi? Tanrının o hüküm anında, önünde, cennete ya da cehenneme gidecek yoldan birine gireceğimi, bu günden bildiğim halde, şimdiden Tanrıya yakarmayayım mı?” (Blau 1959; 53 )

32 "Rab korkusu, bilginin başlangıcıdır. Bilgiden nefret ettiler, Rab korkusunu seçmediler. Rab'den kork, şerden ayrıl. Rab de sevdiğini azarlar. İnsanların gözünde, cezalandırılmış olma, ölümsüzlüğe duydukları ümittir. Emirden korkan, mükafat alır. Küçük bir cezaya uğramış olma, büyük iyilikleri almaya hak kazanmak demektir. Zamanı gelince sonsuz yaşamda saadete eriștirecek olan bedensel acının, ne önemi vardır. Rabbinik yorumuyla İsrail dini, yalnızca gelecekteki yaşam ümidini pekiştirmeye kendilerini alıştırmamakta; fakat bununla birlikte, ne kadar dertli ve sıkıntılı günler içinden geçilirse geçilsin, asla bu yaşamla ilgili ümitlerini kaybetmemeyi de öğrenmişlerdi. İsrailliler için dünyevi yaşam, sadece, üzülerek ve sıkıntıya uğrayarak öbür dünyaya hazırlanılması anlamını içermemekte, kendine özgü sevinç ve hazları da insanlara sunmaktaydı. Yaşamla ilgili böylesine mükemmel bir sonuca ulaşmış olmalarını, Yasaya borçluydular.” (Baech 1941; 104-105)
} 
özellikle iyiliklerin veya kötülüklerin karşılığını bu dünyada mı alınacağı; bu dünyadaki yaşamın Tanrı ödülü veya cezası mı olduğu, yoksa tam tersine, öbür dünyadaki yaşamın şekli için belirleyici bir imtihan yeri mi olduğu vs., biçiminde düşüncelere yol açmıştır. Bu düşüncelerin birbirine zit iki odakta toplanması, İsrail dininde Essene ve Pharisee ahlâğının da birbirine karşıt bir halde oluşmasına neden olduğu gibi; bunlardan ilkinin ilk hristiyanlığa, ikincisinin ise özellikle püritenizme yol açmış olduğu, sonradan yapılan araştırmalarla kesinlikle tanıtlanmış durumdadır.

\section{Sonuç}

İnsanlık tarihinde tek tanrı olarak tapılan ilk ilahın Mısırlıların Güneş tanrısı Ikhneton (Aton) olmasına rağmen, günümüzde Judaistler, tektanrıcılığın İsraillilerin tanrısı Yahve ile başladığını büyük bir gururla öne sürmektedir. Zira Aton, onlarca tanrı ve tanrıça içinde tek tanrı olarak tapılmaya ya da diğerlerinin arasından sivrilmeye başlamıştır ama, diğer tanrı ve tanrıların varlığına son verememiş veya çoktanrıcılığı alt edememiştir. İnsanlar ile tanrılar arasındaki soy ve asalet bağını cinsiyetsizliğiyle kırmaya yeltenen böylece insanın (özellikle de firavunların) tanrısallığını yadsıyan Aton gibi, İsraillilerin tanrısı Yahve de cinsiyetsizdir; tek tanrılığını, insan ya da hayvan olsun tanrı diye tapılan tüm diğer varlıklara olan kıskançlığı ve husumeti üzerine kurmuştur. Tektanrıcılıkta Aton'un diğer ilah ve ilahlar karşısındaki güçsüzlügü iddiasının yanında; Yahve'nin de, tüm insanların değil de yalnızca İsraillilerin tanrısı olma gibi bir engeli ya da yetersizliği vardır. Oysa tek tanrı inancı, evrenselliği ve yaratıcılığı gerektirdiği gibi, her şeye kadir olma niteliğinin yanında bütün insanlara sevgiyle ve dostlukla yaklaşmayı zorunlu kılar. Var olan her şeyin tek yaratıcısı olan bu tek tanrı, her şeye kadir olduğu için; öfkelenmez, tehditler savurmaz, yemin içerek kendini alçaltmaz, insanlar arasında savaş çıkarmaz, yenilgilerle ve belalarla rahatlamaz, insani duygular taşımaz.

Yahve'nin tek tanrıcılığı iddiasının karşısında en büyük engel, yalnızca, tek bir ulusun tanrısı olması ve dolayısıyla ulus bilincine dayanması değildir. Eski Ahit'te sürekli olarak her şeye kadir tanrı olarak övülmüş olmasına rağmen, Tevrat'ta, kekeme Musa'nın tüm yakarmalarına ve ısrarlarına rağmen dilini açamamış, onunla öfkeli bir tartışmaya girerek kardeşi Harun'u yanında görevlendirmiş ve böylece de tek tanrılığın (ya da her şeyin tek yaratıcısı olma iddiasının) dayanağı olan her şeye gücü yeter niteliğini yıkmıştır. Tek yaratıcılık niteliği olmaksızın tek tanrıcılık iddiası boşa gideceği gibi, her şeye kadir olamayan bir tanrı da tek tanrı da olamaz. Ulus tanrısı olan Yahve'nin, tüm diğer insanları karşısına alması ve hepsine karşı husumet saçması yetmiyormuş gibi; seçtiği halkla yaptığı anlaşmayı yasa olarak meşrulaştırmış, bu yasasındaki tüm hükümlerini de kardeş-yabancı ayrımına göre oluşturmuştur. Tüm dinlerde var olan cemaat içi ve cemaat dışı çifte standart davranış normları, Yahve yasasında (ya da Eski Ahit'te) İsrailli olan ile olmayan ayrımı üzerine kurmuştur. Yasası ölçeğinde cezasını ve ödülünü bu dünyada veren, dolayısıyla merhametsiz adaletini gelecek nesiller üzerinde gösteren Yahve'nin; melekleri ve zebanileri, cennet ve cehennemi olmadığı gibi; insanlar arasında eşitliğe dayanan adaleti yoktur. 
İnsan ayrımı yapmak ya da yasa haline getirdiği buyruklarını insan ayrımcılığı üzerine kurmak, yani kardeşe haram kıldığını yabancıya helal görmek, kavim tanrıcılığının temel niteliği olduğu gibi, tek tanrıcılığın evrensel özelliğinin karşısında ciddi bir engeldir. Örneğin Musa şeriatinde faiz yasağında çirkin çehresini gösteren bu insan ayrımcılığı, kardeşi yaratan Yahve'dir de yabancıyı yaratan Yahve değil midir itirazını haklı kılar. Böyle bir itiraza, gerçekte bir kavim tanrısı olan Yahve'nin buyruklarına uymayan herkes yabancıdır tarzında verilecek bir yanıt da, gene tektanrıcılık gereklerine uymamaktadır. Her şeye kadir tanrı, bütün insanları ve tüm varlıkları yaratmış tanrı; kendi yarattığı insana söz geçiremiyor, tehditler savurarak veya yeminler içerek kendini alçaltıyor, insanlara savaş açıyor ve savaş hileleri yapıyorsa, o gerçek tanrı değil, olsa olsa insan zihninde uyanmış algısal bir tanrıdır. Yahve, güçsüz ve cinsiyetsiz olmasının yanında kıskanç ve savaşçı olduğu kadar yağma ve hırsızlık emirleri verecek kadar kötülük saçan bir tanrıdır.

Eski Ahit metinlerinden de açıkça okunacağı gibi, İsraillilerin tek tanrısı Yahve, insan ayrımcılığı yapmaktadır, çifte standart buyruklarını yasa olarak uygulattırmıştır, savaşçıdır, felaketleri ve kötülükleri gönderendir. Böyle olduğu halde, rabbinik yazınıyla oluşturulmuş judaist kaynaklarda, Yahve, dünya kötülük yeri olduğu için dünyanın dışındadır. Her nasılsa Yahve, dünyanın dışında fakat insanın içindedir. Yahveizmde, Tanrının her şeyden üstün olarak yapayalnız bir halde bulunması düşüncesinden, bu dünyanın dışında olduğu kadar içinde de bulunduğu inancına ulaşılmıştır. Özellikle de, Tanrının insanla daha ezelden kurmuş olduğu bağıntısı dikkâte alındığında; Kendisine tapınan ve sevgiyle bağlılık duyan her sâlih kimsenin daima yakınında olduğu bilinci aşılanmak istenmiştir. Dindar İsraillinin Tanrısıyla kuracağı bağlantısı, Tanrının nebilerine doğrudan bildirmiş olduğu Yasası yoluyla davranışlarında itaatkâr olmasına bağlıdır ve Tanrıdan korkulması gerektiği duygusu üzerinde odaklaşmıştır. Tanrının, korkutucu ve uyarıcı tehditlerde bulunma eğilimini hiç bir zaman kaybetmemiş olması; Yahveistin Tanrı'yı sevdiği ölçüde korkmasına yol açmıştır. Bu nedenle dindar İsrailliler, kişinin günaha düşmesinin veya yasayı hiçe saymasının bir sonucu olarak, Tanrının öfkesini fazlasıyla hak edeceğine, ölümden de beter olan bir cezaya uğratılacağına inanmaktadırlar. Ölümden sonraki hayatı ima eden Tevrat sonrası Eski Ahit metinlerin etkisiyle, cezanın veya ödülün bu dünyada $\mathrm{m} 1$ verileceği, yoksa, gelecekteki yaşamın sırf bu maksatla mı yaratılmış olacağı, İsrailli din bilginlerini birbirlerine düşüren konular arasında yer almıştır.

\section{K A Y N A K L A R}

Baech L. (1941). The Essence of Judaism, Macmillan Publishers, London Blau J.L. (1959). Essays on Jewish Life and Thought, Philosophical Library, New York

Bokser B.Z. (1951). The wisdom of the Talmud; a thousand years of Jewish thought, Philosophical Library, New York, 1951

Epstein I, (1964). Judaism, Penguin Books, New York 
Friedlander M. (1937). The Jewish Religion, Macmillan Publishers, London Heschel A.J. (1956). God in Search of Man : A Philosophy of Judaism, Philadelphia University Press, Philadelphia

Jacobs L. (1998). A Jewish Theology, New York University Press, New York Joseph M. (1964). Judaism as Creed and Life, Weidenfeld-Nicolson, London Kohler L (1956). Hebrew Man, Macmillan Publishers, London

Roth L. (1974). Judaism : A Portrait, Oxford University Press, New York Steinberg M. (1953). Basic Judaism, New York University Press, New York 